\title{
Synthesis and characterization of new meso-substituted unsymmetrical metalloporphyrins
}

\author{
BABASAHEEB P BANDGAR* and PRADIP B GUJARATHI \\ Organic Chemistry Research Laboratory, School of Chemical Sciences, Swami Ramanand Teerth \\ Marathwada University, Nanded 431606 \\ e-mail: bandgar_bp $@$ yahoo.com
}

MS received 25 November 2007; revised 17 January 2008

\begin{abstract}
The synthesis and characterization of new meso-substituted unsymmetrical metalloporphyrins has been described. A new modified Adler method was used for the synthesis of two unsymmetrical porphyrins. Reactions of these unsymmetrical porphyrins with metal acetates afforded the corresponding metalloporphyrins in high yields with excellent purity. These porphyrins and their metal derivatives were characterized by spectroscopic methods. However, the copper complexes were further studied by ESR spectra and zinc complex by fluorescence spectrum.
\end{abstract}

Keywords. meso-functionalization; unsymmetrical metalloporphyrins; EPR; fluorescence; metal-ligand interaction.

\section{Introduction}

Porphyrins are unique class of compounds with potential applications in all disciplines of science, including medicine. ${ }^{1}$ The electronic properties of porphyrins can be changed by introducing suitable substituents at the meso-position or $\beta$-position. Porphyrins and metalloporphyrins are essential to the life of bacteria, fungi, plants and animals and have received considerable attention from many investigators in various fields. Synthetic porphyrins, especially meso-tetraphenylporphyrin derivatives substituted in the para-positions with soluble acidic, basic and neural groups are of potential interest in medicinal chemistry because they can form chelates either with some toxic heavy metals or with a gamma-ray emitting radioisotopes. ${ }^{2-4}$

Synthesis and functionalization of porphyrins have received much attention. This has been mainly due to the use of these compounds in catalysis, ${ }^{5}$ photodynamic therapy of cancer cells, ${ }^{6}$ as materials with novel electrical properties ${ }^{7}$ and as biomimetic model systems of primary processes of natural photosynthesis. ${ }^{8}$ Cationic water soluble porphyrins and their metal complexes have been a subject of interest due to their strong affinities for DNA and potential nuclease activity. ${ }^{9}$

\footnotetext{
*For correspondence
}

Metal complexes of tetrapyrrolic macrocycles play a key role with respect to life on earth because of their implications in a variety of enzymetic systems. ${ }^{10}$ Their ability to carry out the reactions rather unusual in organic chemistry has been the object of intensive investigations aiming to utilize them as a model compounds for biological systems and as catalysts. ${ }^{11}$ Therefore, the synthesis of well defined meso-substituted unsymmetrical porphyrin derivatives $\left(A_{3} B\right)$ is of great interest for development of new molecular structures. Two unsymmetrical porphyrins $\left(\mathrm{A}_{3} \mathrm{~B}, 1\right.$ and 2$)$ were synthesized using modified Adler method ${ }^{12}$ (scheme 1).

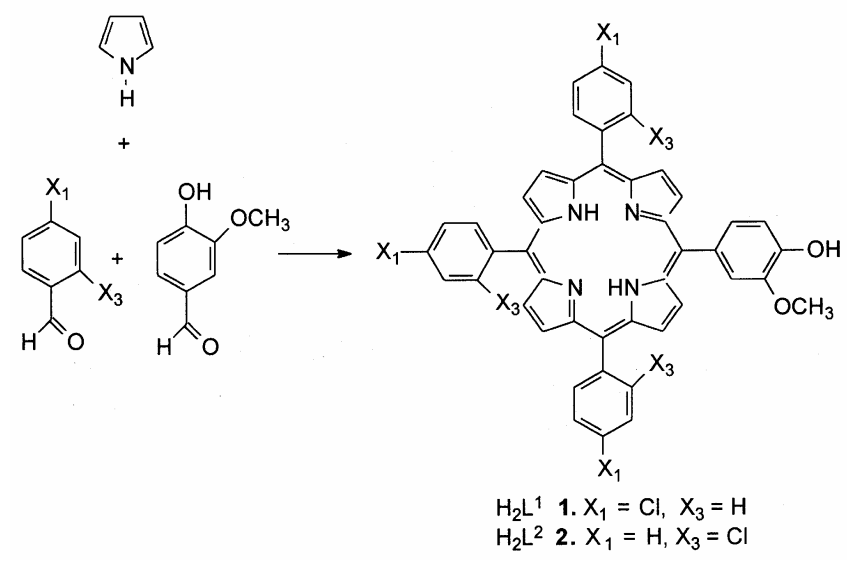

Scheme 1. Synthesis of porphyrin (1 and 2). 


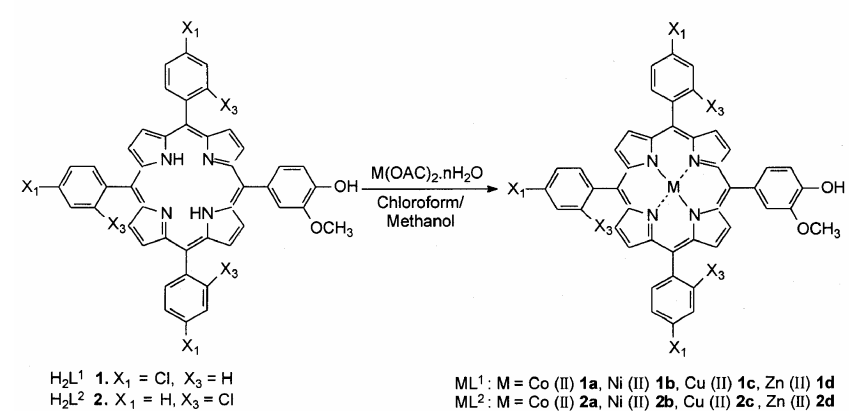

Scheme 2. Synthesis of metalloporphyrin (1a-1d and 2a-2d).

We report here convenient synthesis of some metalloporphyrins (1a-1d and $\mathbf{2 a - 2 d )}$ using mesosubstituted unsymmetrical porphyrins ( $\mathrm{A}_{3} \mathrm{~B}$-type) (scheme 2).

\section{Experimental}

The pyrrole and proponic acid were distilled before use. The IR spectra were recorded on Shimadzu infrared spectrophotometer (FT-IR-8400). The FarIR spectra were recorded on Megna IR spectrometer (550 Nicolet). The NMR spectra were recorded on Varian (mercury YH-300) of $300 \mathrm{MHz}$ using tetramethylsilane as internal standard. UV-Visible spectra were obtained on Shimadzu UV-spectrometer (UV-1601) using chloroform. Fluorescence spectra were recorded on Shimadzu spectrofluorophotometer (RF-5301 PC) in chloroform. Mass spectra were obtained on micromass (Q-TOF micro YA-105) using chloroform. Elemental analysis was carried out on Perkin Elmer (240c) elemental analyzer. ESR spectra were recorded on Brucker EMX EPR spectrometer (ER 041 XG-microwave bridge X-band and EPR spectrometer (Varian) with solid polycrystalline sample at room temperature and under liquid nitrogen (LNT). Silica gel (60-120 mesh) was used for column chromatography.

\subsection{Synthesis of macrocycles and their complexes}

5-[(4-Hydroxy-3-methoxy)phenyl]-10, 15, 20-tris(4chlorophenyl)porphyrin $\left(\mathrm{H}_{2} \mathrm{~L}^{1}, 1\right)$ and 5-[(4-hydroxy3-methoxy)phenyl]-10, 15, 20-tris(2-chlorophenyl)porphyrin $\left(\mathrm{H}_{2} \mathrm{~L}^{2}, 2\right)$ were prepared using modified Adler method. ${ }^{12}$

2.1a Synthesis of [5-[(4-hydroxy-3-methoxy)phenyl]10,15,20-tris(4-chlorophenyl)porphyrinato] cobalt
(II) complex $\left(\mathrm{CoL}^{1}\right)$ (1a): A mixture of porphyrin $\left.\left(\mathrm{H}_{2} \mathrm{~L}^{1}\right) 83.63 \mathrm{mg}, 0.1 \mathrm{mmol}\right)$ in $\mathrm{CHCl}_{3}(10 \mathrm{ml}$ and $\mathrm{Co}(\mathrm{OAC})_{2} \cdot 4 \mathrm{H}_{2} \mathrm{O}(49.8 \mathrm{mg}, 0.2 \mathrm{mmol})$ in methanol $(10 \mathrm{ml})$ was stirred at $60^{\circ} \mathrm{C}$ for $30 \mathrm{~min}$. After completion of reaction as indicated by TLC, the reaction mixture was cooled at room temperature. The solvent was evaporated under vacuum to afford crude product, which was purified by column chromatography (silica gel, $\mathrm{CHCl}_{3}$ : pet ether $=6: 4$ ). A second moving band was collected and after evaporation of solvent furnished radish pink as a title compound (1a); Yield: $71.5 \mathrm{mg}, 80 \%$.

UV-Visible $\left(\lambda_{\max }\right): 408,529 \mathrm{~nm}$; IR $(\mathrm{KBr}): 630 \cdot 7$, $717 \cdot 5,802 \cdot 3,933 \cdot 8,1004 \cdot 8,1170,1263 \cdot 3,1348 \cdot 1$, $1392 \cdot 5,1452 \cdot 3,1492 \cdot 8,1596 \cdot 3,2931 \cdot 6,3057 \cdot 0$, $3533.3 \mathrm{~cm}^{-1}$; Mass (TOF - MSES + 590) $\mathrm{m} / \mathrm{z}(\%)$ : $821 \cdot 185$.

Anal calcd. for $\mathrm{C}_{45} \mathrm{H}_{27} \mathrm{~N}_{4} \mathrm{O}_{2} \mathrm{Cl}_{3} \mathrm{Co} \cdot 4 \mathrm{H}_{2} \mathrm{O}$ (\%): C, $60 \cdot 51 ; \mathrm{H}, 3 \cdot 94 ; \mathrm{N}, 6 \cdot 27$.

Found: (\%): C, 60.42; H, 3.90; N, 6.17 .

2.1b Synthesis of [5-[(4-hydroxy-3-methoxy) phenyl]-10,15,20-tris(4-chlorophenyl)porphyrinato] nickel (II) complex $\left(\mathrm{NiL}^{1}\right)$ (1b): A mixture of porphyrin $\left(\mathrm{H}_{2} \mathrm{~L}^{1}\right)(83.631 \mathrm{mg}, 0.1 \mathrm{mmol})$ in $\mathrm{CHCl}_{3}(10 \mathrm{ml})$ and $\mathrm{Ni}(\mathrm{OAC})_{2} \cdot 4 \mathrm{H}_{2} \mathrm{O} \quad(49.76 \mathrm{mg}, \quad 0.2 \mathrm{mmol})$ in methanol $(10 \mathrm{ml})$ was stirred at $50^{\circ} \mathrm{C}$ for $3 \mathrm{~h}$. After completion of reaction as indicated by TLC, the solvent was removed under reduced pressure. Then crude product was purified by column chromatography (silica gel, $\mathrm{CHCl}_{3}$; per ether $=8: 2$ ) to yield title compound (1b) as a purple solid; Yield: $71 \cdot 44,80 \%$.

UV-Visible $\left(\lambda_{\max }\right): 416,479,528 \cdot 0 \mathrm{~nm}$; IR $(\mathrm{KBr})$ : $713 \cdot 6,804 \cdot 3,1089 \cdot 7,1203 \cdot 5,1261 \cdot 4,1350 \cdot 1,1454 \cdot 2$, $1502.4,1558.4,1652 \cdot 9,1845 \cdot 7,2374 \cdot 2,2983.7$, $3180 \cdot 4,3649 \cdot 1 \mathrm{~cm}^{-1}$; ${ }^{1} \mathrm{H}-\mathrm{NMR}\left(300 \mathrm{MHz}, \mathrm{CDCl}_{3}\right)$ ): $1.25-1.55\left(\right.$ br s $\left., 3 \mathrm{H}, \mathrm{OCH}_{3}\right), 3.95\left(s, 3 \mathrm{H}, \mathrm{OCH}_{3}\right)$, 5.95 ( $m, 1 \mathrm{H}, \mathrm{Ar}-\mathrm{OH}), 7 \cdot 15-7.65$ ( $m, 12 \mathrm{H}, \mathrm{Ar}-\mathrm{H}), 7.95$ ( $m, 3 \mathrm{H}, \mathrm{Ar}-\mathrm{H}), 8 \cdot 7-8.85(\mathrm{~m}, 8 \mathrm{H}$, pyrrole-H); Mass (TOF - MSES + 350) $\mathrm{m} / z(\%): 820 \cdot 89$.

Anal calcd. for $\mathrm{C}_{45} \mathrm{H}_{27} \mathrm{~N}_{4} \mathrm{O}_{2} \mathrm{Cl}_{3} \mathrm{Ni} \cdot 4 \mathrm{H}_{2} \mathrm{O}$ (\%): $\mathrm{C}$, 60.52; H, 3.95; N, 27.

Found (\%): C, 60.40; H, 3.62; N, 6.19.

2.1c Synthesis of [5-[(4-hydroxy-3-methoxy)phenyl]10,15,20-tris(4-chlorophenyl)porphyrinato] copper (II) complex $\left(\mathrm{CuL}^{1}\right)$ (1c): A mixture of porphyrin $\left(\mathrm{H}_{2} \mathrm{~L}^{1}\right) \quad(100.35 \mathrm{mg}, \quad 0.12 \mathrm{mmol})$ in chloroform $(10 \mathrm{ml})$ and $\mathrm{Cu}(\mathrm{OAC})_{2} \mathrm{H}_{2} \mathrm{O}(39.92 \mathrm{mg}, 0.2 \mathrm{mmol})$ in methanol $(5 \mathrm{ml})$ was stirred for $2 \mathrm{~h}$. After completion of reaction as indicated by TLC, the solvent was 
removed. The residue was washed with water and extracted with chloroform. The organic layer dried over anhydrous $\mathrm{Na}_{2} \mathrm{SO}_{4}$, concentrated in vacuo to afford pink solid as a title compound (1c); Yield: $96.92 \mathrm{mg}, 90 \%$.

UV-Visible $\left(\lambda_{\max }\right): 413 \cdot 0,539 \mathrm{~nm}$; IR $(\mathrm{KBr})$ : $717 \cdot 5,802 \cdot 3,929 \cdot 3,1002 \cdot 9,1168 \cdot 8,1203 \cdot 5,1344 \cdot 3$, $1492 \cdot 8,1577 \cdot 7,3045 \cdot 4,3527.6 \mathrm{~cm}^{-1}$; Far IR: $151 \cdot 9$, $255.4, \quad 337 \cdot 1, \quad 421 \cdot 1, \quad 505 \cdot 1 \mathrm{~cm}^{-1}$; Mass (TOF MSES + 2.07 e3) $m / z(\%): 826 \cdot 2\left(\mathbf{M}^{+}\right)$.

Anal calcd. for $\mathrm{C}_{45} \mathrm{H}_{27} \mathrm{~N}_{4} \mathrm{O}_{2} \mathrm{Cl}_{3} \mathrm{Cu} \cdot 4 \mathrm{H}_{2} \mathrm{O}$ (\%): $\mathrm{C}$, $60 \cdot 20 ; \mathrm{H}, 3 \cdot 92 ; \mathrm{N}, 6 \cdot 24$.

Found (\%): C, 60.00; H, 3.82, N, 6.19.

2.1d Synthesis of [5-[(4-hydroxy-3-methoxy)phenyl]10,15,20-tris(4-chlorophenyl)porphyrinato] zinc (II) complex $\left(Z n L^{1}\right)(\mathbf{l d})$ : A mixture of porphyrin $\left(\mathrm{H}_{2} \mathrm{~L}^{1}\right)(83.631 \mathrm{mg}, 0.1 \mathrm{mmol})$ in chloroform $(8 \mathrm{ml})$ and $\mathrm{Zn}(\mathrm{OAC})_{2} \cdot 2 \mathrm{H}_{2} \mathrm{O}(39.51 \mathrm{mg}, 0 \cdot 18 \mathrm{mmol})$ in methanol $(8 \mathrm{ml})$ was stirred at room temperature for $4 \mathrm{~h}$. After removal of solvent under reduced pressure, the residue was washed with water to remove excess metal acetate. The residue was then extracted with chloroform, organic layer was dried over anhydrous $\mathrm{Na}_{2} \mathrm{SO}_{4}$, and removal of solvent under reduced pressure afforded purple solid as a title compound (1d); Yield: $71.9 \mathrm{mg}, 80 \%$.

UV-Visible $\left(\lambda_{\max }\right)$ : $428,555,596.0 \mathrm{~nm}$; IR $(\mathrm{KBr})$ : $719 \cdot 4,852 \cdot 5,933 \cdot 5,1255 \cdot 6,1338 \cdot 5,1446 \cdot 5,1598 \cdot 9$, $1978.8,2366 \cdot 5,2599.9,3159.9,3643.3 \mathrm{~cm}^{-1}$; Far IR: $144 \cdot 1,162 \cdot 8,180 \cdot 7,209 \cdot 5,295.8,333.2 \mathrm{~cm}^{-1}$; ${ }^{1} \mathrm{H}-\mathrm{NMR}\left(300 \mathrm{MHz}, \mathrm{CDCl}_{3}\right): 1 \cdot 15-1 \cdot 5(\mathrm{br} s, \mathrm{OH}$ of $\left.\mathrm{H}_{2} \mathrm{O}\right), 3.95\left(s, 3 \mathrm{H}, \mathrm{OCH}_{3}\right), 5.95(s, 1 \mathrm{H}, \mathrm{Ar}-\mathrm{OH})$, 7.25-7.75 ( $m, 12 \mathrm{H}, \mathrm{Ar}-\mathrm{H}), 8.15$ ( $m, 3 \mathrm{H}, \mathrm{Ar}-\mathrm{H}), 8.95$ $(\mathrm{m}, 8 \mathrm{H}$, pyrrole-H); Mass (TOF - MSES +400$) \mathrm{m} / \mathrm{z}$ (\%): 830.4205 (M $\left.{ }^{+}\right)$.

Anal calcd. for $\mathrm{C}_{45} \mathrm{H}_{27} \mathrm{~N}_{4} \mathrm{O}_{2} \mathrm{Cl}_{3} \mathrm{Zn} \cdot 4 \mathrm{H}_{2} \mathrm{O}$ (\%): C, 60.07; H, 3.92; N, 6.22.

Found (\%): C, 60.09; H, 3.70, N, 5.90.

2.1e Synthesis of [5-[(4-hydroxy-3-methoxy)phenyl]10,15,20-tris(2-chlorophenyl)porphyrinato] cobalt (II) complex $\left(\mathrm{CoL}^{2}\right)$ (2a): A mixture of porphyrin $\left(\mathrm{H}_{2} \mathrm{~L}^{2}\right)(83.631 \mathrm{mg}, 0 \cdot 1 \mathrm{mmol})$ in $\mathrm{CHCl}_{3}(10 \mathrm{ml})$ and $\mathrm{Co}(\mathrm{OAC})_{2} \cdot 4 \mathrm{H}_{2} \mathrm{O}(49.8 \mathrm{mg}, 0.2 \mathrm{mmol})$ in methanol $(10 \mathrm{ml})$ was stirred at $60^{\circ} \mathrm{C}$ for $30 \mathrm{~min}$. After completion of reaction as indicated by TLC, the reaction mixture was cooled at room temperature. The solvent was evaporated under vacuum to afford crude product, which was purified by column chromatography (silica gel, $\mathrm{CHCl}_{3}$ : pet ether $=5: 5$ ). A second moving band was collected and after evaporation of solvent yielded pink solid as a title compound (2a); Yield: $80.4 \mathrm{mg}, 90 \%$ ).

UV-Visible $\left(\lambda_{\max }\right): 410 \cdot 5,529.50,652.50 \mathrm{~nm} ; \mathrm{IR}$ (KBr): 715.5, 754.1, 873.7, 939.3, 1004.8, 1126.4, $1163 \cdot 0,1265 \cdot 5,1348 \cdot 1,1434 \cdot 9,1512 \cdot 1,1562 \cdot 2$, 2939.3, 3375.2, $3516.0 \mathrm{~cm}^{-1}$; Far IR: $69 \cdot 4,92 \cdot 0$, $145.7, \quad 193.1,273.3,285.7 \mathrm{~cm}^{-1}$; Mass (TOF MSES + 599) $\mathrm{m} / \mathrm{z}(\%): 821.33\left(\mathbf{M}^{+}\right)$.

Anal calcd. for $\mathrm{C}_{45} \mathrm{H}_{27} \mathrm{~N}_{4} \mathrm{O}_{2} \mathrm{Cl}_{3} \mathrm{Co} \cdot 4 \mathrm{H}_{2} \mathrm{O}$ (\%): $\mathrm{C}$, $60 \cdot 51 ; \mathrm{H}, 3 \cdot 94 ; \mathrm{N}, 6 \cdot 27$.

Found (\%): C, 60.48; H, 3.91, N, 6.26.

2.1f Synthesis of [5-[(4-hydroxy-3-methoxy)phenyl]10,15,20-tris(2-chlorophenyl)porphyrinato] nickel (II) complex $\left(\mathrm{NiL}^{2}\right)(\mathbf{2 b})$ : A mixture of porphyrin $\left(\mathrm{H}_{2} \mathrm{~L}^{2}\right)(83.631 \mathrm{mg}, 0.1 \mathrm{mmol})$ in $\mathrm{CHCl}_{3}(10 \mathrm{ml})$ and $\mathrm{Ni}(\mathrm{OAC})_{2} \cdot 4 \mathrm{H}_{2} \mathrm{O}(49.76 \mathrm{mg}, 0.2 \mathrm{mmol})$ in $\mathrm{CH}_{3} \mathrm{OH}$ $(15 \mathrm{ml})$ was stirred at $60^{\circ} \mathrm{C}$ for $4 \mathrm{~h}$. After evaporation to dryness under vacuum, the residue was purified by column chromatography (silica gel, $\mathrm{CHCl}_{3}$ : pet ether $=5: 5$. The second pink band was collected and after evaporation of solvent afforded pink solid as a title compound (2b); Yield: $77.44 \mathrm{mg}, 80 \%$.

UV-Visible $\left(\lambda_{\max }\right): 420 \cdot 0,544,583 \mathrm{~nm}$; IR $(\mathrm{KBr})$ : $451 \cdot 3,640 \cdot 3,715 \cdot 5,752 \cdot 2,796 \cdot 5,1068 \cdot 5,1120 \cdot 6$, $1163.0,1261.4,1336 \cdot 6,1429 \cdot 2,1467 \cdot 7,1510 \cdot 2$, $1595 \cdot 0,2366.5,3689.6 \mathrm{~cm}^{-1}$; ${ }^{1} \mathrm{H}-\mathrm{NMR}(300 \mathrm{MHz}$, $\left.\mathrm{CDCl}_{3}\right): 1 \cdot 15-1.55\left(\mathrm{br} \mathrm{s}, \mathrm{OH}\right.$ of $\left.\mathrm{H}_{2} \mathrm{O}\right), 3.95(s, 3 \mathrm{H}$, $\left.\mathrm{OHC}_{3}\right), 5.95(s, 1 \mathrm{H}, \mathrm{Ar}-\mathrm{OH}), 7.25-7.65(m, 12 \mathrm{H}$, Ar-H), 8.15 ( $m, 3 \mathrm{H}, \mathrm{Ar}-\mathrm{H}), 8 \cdot 85-9.0(m, 8 \mathrm{H}$, pyrrole-H); Mass (TOF - MSES + 360) $\mathrm{m} / z \quad$ (\%): $820 \cdot 62$.

Anal calcd. for $\mathrm{C}_{45} \mathrm{H}_{27} \mathrm{~N}_{4} \mathrm{O}_{2} \mathrm{Cl}_{3} \mathrm{Ni} \cdot 4 \mathrm{H}_{2} \mathrm{O}$ (\%): $\mathrm{C}$, 60.52; H, 3.95; N, 6.27.

Found (\%): C, 60.43; H, 3.82, N, 6.20.

$2.1 \mathrm{~g}$ Synthesis of [5-[(4-hydroxy-3-methoxy)phenyl]10,15,20-tris(2-chlorophenyl)porphyrinato] copper (II) complex $\left(\mathrm{CuL}^{2}\right)(2 \mathrm{c})$ : A mixture of porphyrin $\left(\mathrm{H}_{2} \mathrm{~L}^{2}\right)(83.63 \mathrm{mg}, 0.1 \mathrm{mmol})$ in chloroform $(8 \mathrm{ml})$ and $\mathrm{Cu}(\mathrm{OAC})_{2} \cdot \mathrm{H}_{2} \mathrm{O}(39.93 \mathrm{mg}, 0.2 \mathrm{mmol})$ in methanol $(5 \mathrm{ml})$ was stirred at room temperature for $2 \mathrm{~h}$. After completion of metalation as indicated by TLC, the solvent was removed under reduced pressure. The residue was washed with water and extracted with chloroform. The organic layer dried over anhydrous $\mathrm{Na}_{2} \mathrm{SO}_{4}$, concentrated in vacuo to afford reddish pink solid as a title compound (2c). Yield: $71.44 \mathrm{mg}, 80 \%$.

UV-Visible $\left(\lambda_{\max }\right): 415.50,540,619 \mathrm{~nm} ; \quad I R$ (KBr): 715.5, 754.1, 798.5, 933.5, 1001.0, 1122.5, 
Table 1. UV-visible spectroscopic data of free base porphyrins $\left(\mathrm{H}_{2} \mathrm{~L}^{1}, \mathbf{1}\right)$ and metalloporphyrins (1a-1d).

\begin{tabular}{lccc}
\hline & & \multicolumn{2}{c}{ UV-visible parameter $\left(\lambda_{\max } / \mathrm{nm}\right)$} \\
\cline { 3 - 4 } Porphyrin/metalloporphyrins & Compound no. & Soret & Q bands \\
\hline $\mathrm{H}_{2} \mathrm{~L}^{1}$ & $\mathbf{1}$ & 423 & $517,552,591,648$ \\
$\mathrm{CoL}^{1}$ & $\mathbf{1 a}$ & 408 & 529 \\
$\mathrm{NiL}^{1}$ & $\mathbf{1 b}$ & 416 & 479,528 \\
$\mathrm{CuL}^{1}$ & $\mathbf{1 c}$ & 413 & 539 \\
$\mathrm{ZnL}^{1}$ & $\mathbf{1 d}$ & 428 & 555,596 \\
\hline
\end{tabular}

$1163 \cdot 0,1203 \cdot 5,1263 \cdot 3,1342 \cdot 4,1433 \cdot 0,1512 \cdot 1$, $1598.9,2356 \cdot 9,3444.6 \mathrm{~cm}^{-1}$; Far IR: $164.4,191 \cdot 6$, $218 \cdot 0,263 \cdot 9,296 \cdot 9,316 \cdot 2,330 \cdot 8,365 \cdot 8,405 \cdot 5$, $429 \cdot 6,579.8 \mathrm{~cm}^{-1}$; Mass (TOF - MSES + $1.99 \mathrm{e} 3$ ) $m / z(\%): 826 \cdot 2612\left(\mathbf{M}^{+}\right)$.

Anal calcd. for $\mathrm{C}_{45} \mathrm{H}_{27} \mathrm{~N}_{4} \mathrm{O}_{2} \mathrm{Cl}_{3} \mathrm{Cu} \cdot 4 \mathrm{H}_{2} \mathrm{O}(\%)$ : C, 60.20; H, 3.92; N, 6.24.

Found (\%): C, 60.00; H, 3.72, N, 6.0.

2.1h Synthesis of [5-[(4-hydroxy-3-methoxy)phenyl]10,15,20-tris(2-chlorophenyl)porphyrinato] zinc (II) complex $\left(Z n L^{2}\right)(2 d)$ : A mixture of porphyrin $\left(\mathrm{H}_{2} \mathrm{~L}^{2}\right)(81.61 \mathrm{mg}, 0.1 \mathrm{mmol})$ and $\mathrm{Zn}(\mathrm{OAC})_{2} \cdot 2 \mathrm{H}_{2} \mathrm{O}$ $(54.75 \mathrm{mg}, 0.25 \mathrm{mmol})$ in (chloroform : methanol = $5: 5 \mathrm{ml}$ ) was stirred for $3 \mathrm{~h}$. After completion of metalation as indicated by TLC, the solvent was evaporated under reduced pressure. The residue was extracted with chloroform and dried over anhydrous $\mathrm{Na}_{2} \mathrm{SO}_{4}$, after evaporation of solvent under reduced pressure furnished purple solid as a title compound (2d); Yield: $76.4 \mathrm{mg}, 85 \%$.

UV-Visible $\left(\lambda_{\max }\right): 425,593,693 \mathrm{~nm}$; IR $(\mathrm{KBr})$ : $715 \cdot 5,754 \cdot 1,796 \cdot 5,933 \cdot 5,999 \cdot 1,1068 \cdot 5,1120 \cdot 6$, $1163.0,1261.4,1336 \cdot 6,1512 \cdot 1,1568 \cdot 9,3058.9$, $3525.6 \mathrm{~cm}^{-1}$; ${ }^{1} \mathrm{H}-\mathrm{NMR}\left(300 \mathrm{MHz}, \mathrm{CDCl}_{3}\right)$ : 1.25$1.55\left(b r s, \mathrm{OH}\right.$ of $\left.\mathrm{H}_{2} \mathrm{O}\right), 4 \cdot 0\left(s, 3 \mathrm{H}, \mathrm{OCH}_{3}\right), 6 \cdot 0(s$, $1 \mathrm{H}, \mathrm{Ar}-\mathrm{OH}), 7.25-7.65(\mathrm{~m}, 12 \mathrm{H}, \mathrm{Ar}-\mathrm{H}), 8.15(\mathrm{~m}$, $3 \mathrm{H}, \mathrm{Ar}-\mathrm{H}), 8.65-8.95$ ( $m, 8 \mathrm{H}$, pyrrole-H); Mass (TOF - MSES + 400) $\mathrm{m} / z(\%): 829.52$.

Anal calcd. for $\mathrm{C}_{45} \mathrm{H}_{27} \mathrm{~N}_{4} \mathrm{O}_{2} \mathrm{Zn} \cdot 4 \mathrm{H}_{2} \mathrm{O}(\%)$ : C, 60.07; H, 3.92; N, 6.22.

Found (\%): C, 60.12; H, 3.50, N, 6.0.

\section{Results and discussion}

The meso-substituted unsymmetrical porphyrins $\left(\mathrm{H}_{2} \mathrm{~L}^{1}\right.$ and $\left.\mathrm{H}_{2} \mathrm{~L}^{2}\right)$ in chloroform and different metal acetates (in methanol) were allowed to react resulting in the formation of the corresponding metal complex (scheme 2).

\section{$3.1 U V$-visible spectra}

In free base porphyrins (1) and (2) showed one Soret band near to $400 \mathrm{~nm}$ and four Q bands in visible region. On metallation, the porphyrin ring deprotonates forming dianionic ligand. The metal ions behaved as Lewis acids accepting lone pairs of electrons form dianionic porphyrin ligand. Unlike most transition metal complexes, their colour is due to absorption(s) within the porphyrin ligands involving the excitation of electrons from $\pi$ to $\pi^{*}$ prophyrin ring orbital. ${ }^{13}$ The observation in all complexes indicates that the change in spectrum (fewer peaks) on metalation is due to increased symmetry relative to the free base porphyrins $\left(\mathrm{H}_{2} \mathrm{~L}^{1}\right.$ and $\left.\mathrm{H}_{2} \mathrm{~L}^{2}\right)$. Comparative electronic data for free base porphyrins (1) and (2) and metalloporphyrins (1a-1d, $\mathbf{2 a - 2 d )}$ are listed in tables 1-2 and figures $1-6$.

The two hydrogens on the nitrogen atoms in free base porphyrin reduce the ring symmetry from square (for metalloporphyrins) to rectangular that is from $\mathrm{D}_{4} \mathrm{~h}$ to $\mathrm{D}_{2} \mathrm{~h}$. In general, more symmetrical molecule gives simpler spectrum.

It is observed from tables 1 and 2 that when $\mathrm{Zn}$ binds to porphyrin compound (1) and (2), the absorption spectrum changes owing to the symmetry effect but the $\pi$ to $\pi^{*}$ energy gap is little affected and the regular metalloporphyrins are resulted. In contrast to the other metals (e.g. $\mathrm{Ni}, \mathrm{Co}$ and $\mathrm{Cu}$ ) peaks are shifted to the shorter wavelength due to metal $\mathrm{d} \pi$ ( $d x z$ and $d y z$ ) to prophyrin $\pi^{*}$ back bonding. The electronic spectra of free base ligand 1 and 2 with corresponding complex (1c and 2a) and also comparative spectra are presented in figures 1-6.

\subsection{IR spectra}

The IR spectral data of porphyrins and metalloporphyrins ascertain some functional groups to exist. The $v_{\mathrm{N}-\mathrm{H}}$ absorption band of free base prophyrin is 
Table 2. UV-visible spectroscopic data of free base porphyrin $\left(\mathrm{H}_{2} \mathrm{~L}^{2}, 2\right)$ and metalloporphyrins (2a-2d).

\begin{tabular}{lcll}
\hline & & \multicolumn{2}{c}{ UV-visible parameter $\left(\lambda_{\max } / \mathrm{nm}\right)$} \\
\cline { 3 - 4 } Porphyrin/metalloporphyrins & Compound no. & \multicolumn{1}{c}{ Soret } & \multicolumn{1}{c}{ Q bands } \\
\hline $\mathrm{H}_{2} \mathrm{~L}^{2}$ & $\mathbf{2}$ & 415 & $514 \cdot 5,548,589,650$ \\
$\mathrm{CoL}^{2}$ & $\mathbf{2 a}$ & $410 \cdot 50$ & $529 \cdot 50,652 \cdot 50$ \\
$\mathrm{NiL}^{2}$ & $\mathbf{2 b}$ & 420 & 544,583 \\
$\mathrm{CuL}^{2}$ & $\mathbf{2 c}$ & 415.50 & 540,619 \\
$\mathrm{ZnL}^{2}$ & $\mathbf{2 d}$ & $425 \cdot 0$ & $593.0,693.0$ \\
\hline
\end{tabular}

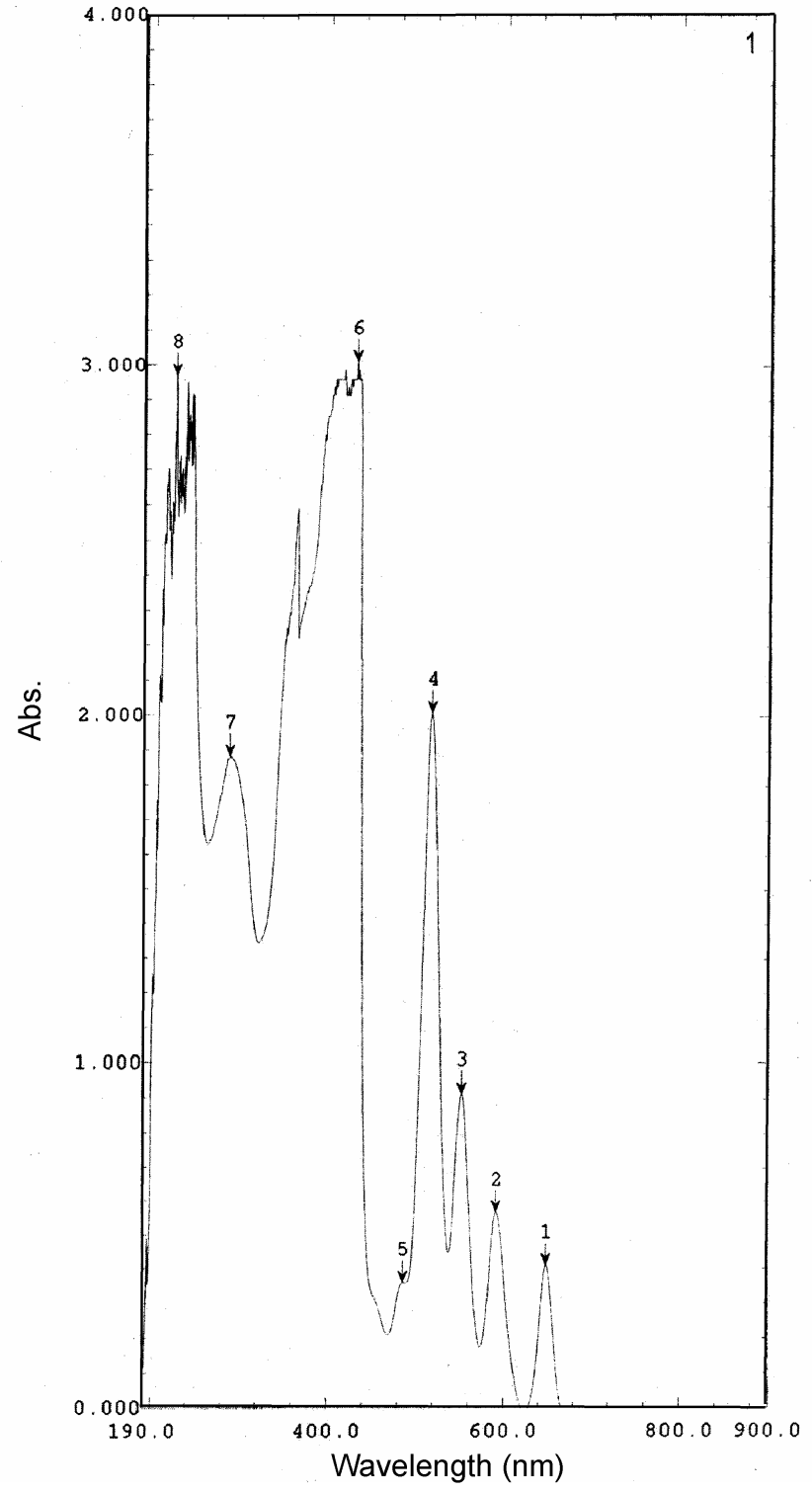

Figure 1. UV-visible spectrum of $\mathbf{1}$.

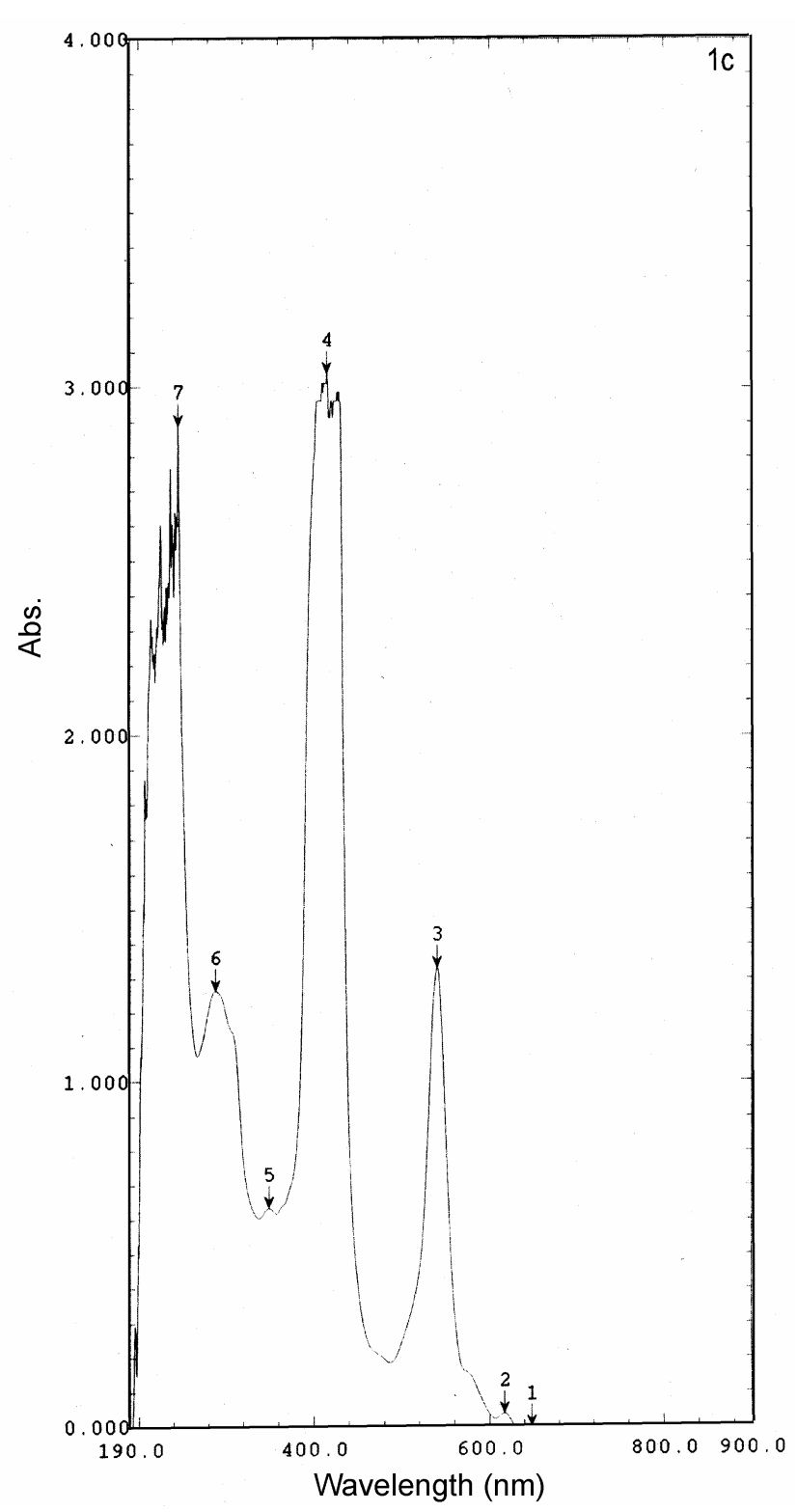

Figure 2. UV-visible spectrum of 1c. at about $3320 \mathrm{~cm}^{-1}, \delta_{\mathrm{N}-\mathrm{H}}$ (in planarity) and $\delta_{\mathrm{N}-\mathrm{H}}$ (out of planarity) absorption band of porphyrin band is about $967 \mathrm{~cm}^{-1}$ and $728 \mathrm{~cm}^{-1}$. The $v_{\mathrm{C}-\mathrm{H}}$ absorption band of porphyrin is about $2920 \mathrm{~cm}^{-1}$. Some peaks that appear in the range of 980 to $710 \mathrm{~cm}^{-1}$ are related to skeletal ring vibrations of free base por- 
Table 3. ESR data for compounds (1c and 2c) at room temperature.

\begin{tabular}{lcccc}
\hline Metalloporphyrins & Compound no. & $g_{\|}(G)$ & $g_{\perp}(G)$ & $A_{\|}(G)$ \\
\hline $\mathrm{CuL}^{1}$ & 1c & $2 \cdot 183$ & $2 \cdot 057$ & $200 \cdot 6$ \\
$\mathrm{CuL}^{2}$ & 2c & $2 \cdot 106$ & $2 \cdot 060$ & 204.8 \\
\hline
\end{tabular}

Table 4. ESR data for compounds (1c and 2c) at LNT.

\begin{tabular}{lccccc}
\hline Metalloporphyrins & Compound no. & $g_{1}$ & $g_{2}$ & $g_{3}$ & $g_{4}$ \\
\hline $\mathrm{CuL}^{1}$ & 1c & $2 \cdot 41$ & $2 \cdot 19$ & $2 \cdot 05$ & 1.98 \\
$\mathrm{CuL}^{2}$ & 2c & $2 \cdot 106$ & $2 \cdot 06$ & - & - \\
\hline
\end{tabular}

All $G>4$

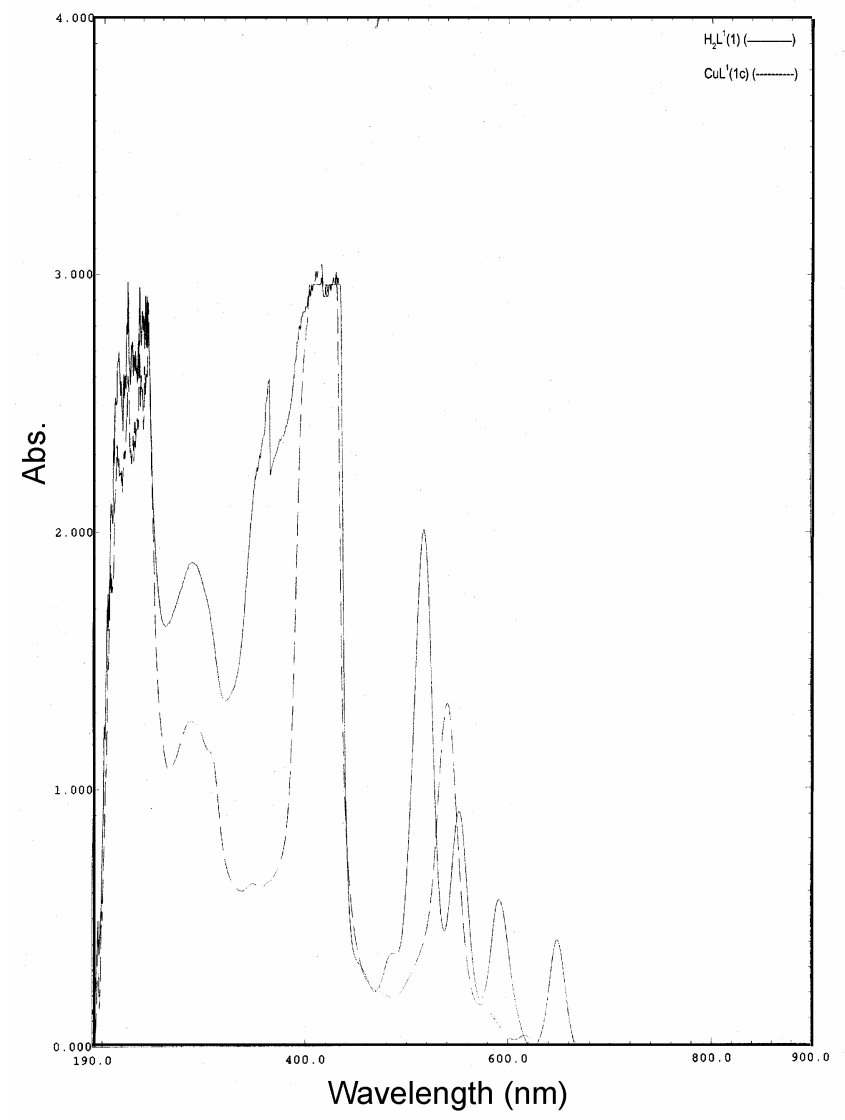

Figure 3. Comparison of UV-visible spectrum of ligand $\mathrm{H}_{2} \mathrm{~L}^{1}$ (1) and $\mathrm{CuL}^{1}(\mathbf{1 c})$.

phyrins. These bands disappear in the all synthesized metalloporphyrins after the metal insertion reactions and strong band near $1000 \mathrm{~cm}^{-1}$ corresponds to skeletal ring vibration of metal porphyrin agree with the result of literature. ${ }^{14-16}$

\section{$3.3 \quad$ NMR spectra}

The ${ }^{1}$ H-NMR data of free base porphyrins (1) and (2) in comparison with metalloporphyrins (1a-d and

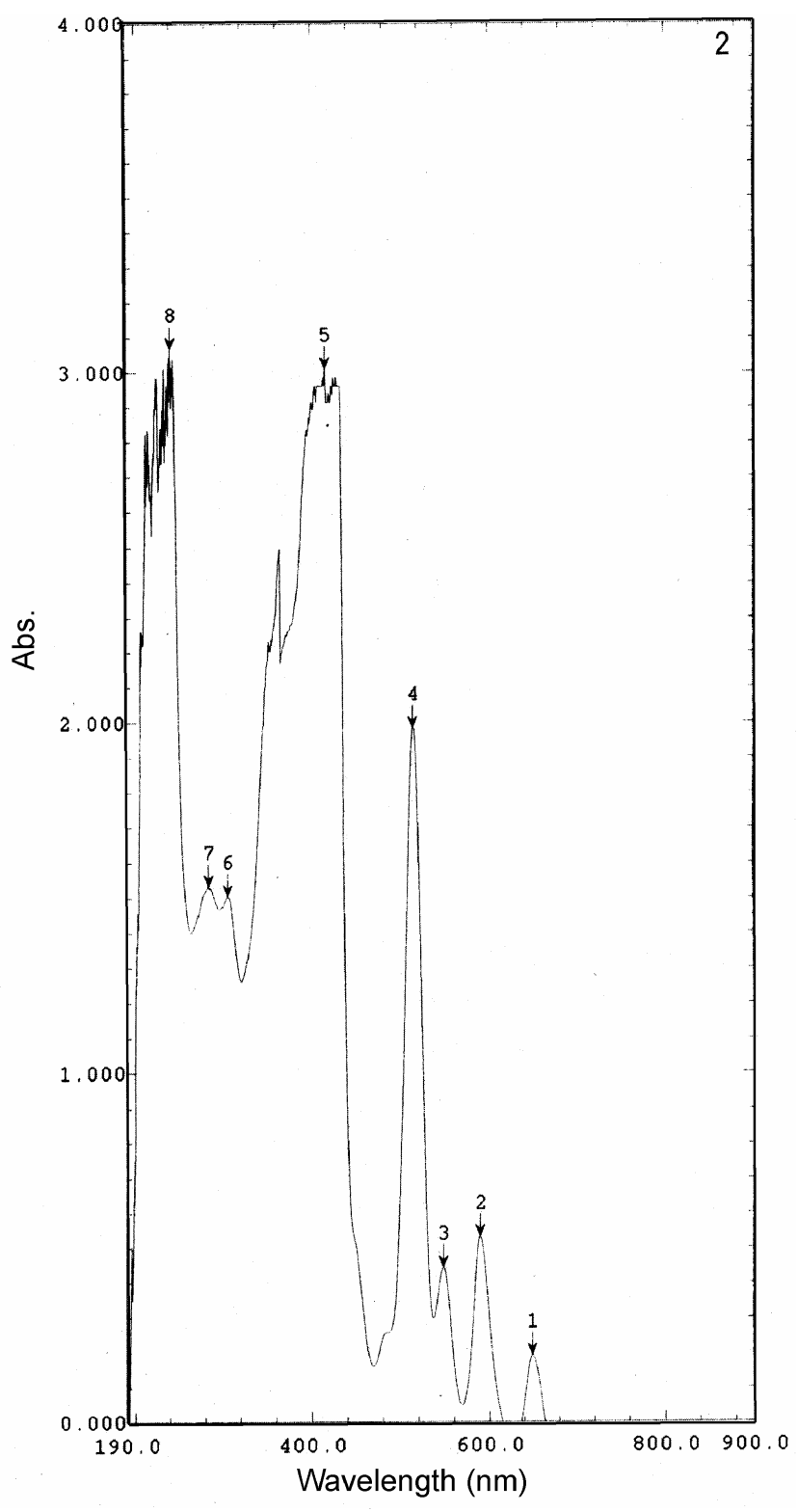

Figure 4. UV-visible spectrum of 2.

2a-d) showed that highly shielded peak at around $-2.9 \mathrm{ppm}$ is the $\mathrm{N}-\mathrm{H}$ at the center of porphyrin ligand 
and this peak disappeared after complexation of porphyrin with metal because the two $\mathrm{H}$ atom are replaced by metal ion. ${ }^{15}$ This is a great movement to high field on the basis of strong shield effect of porphyrin ring.

\subsection{ESR spectra}

Electron spin resonance study of complexes (1c) and (2c) was carried out at room temperature and under liquid nitrogen temperature. A large number of investigators working on porphyrins and related systems have utilized this method in probing into struc-

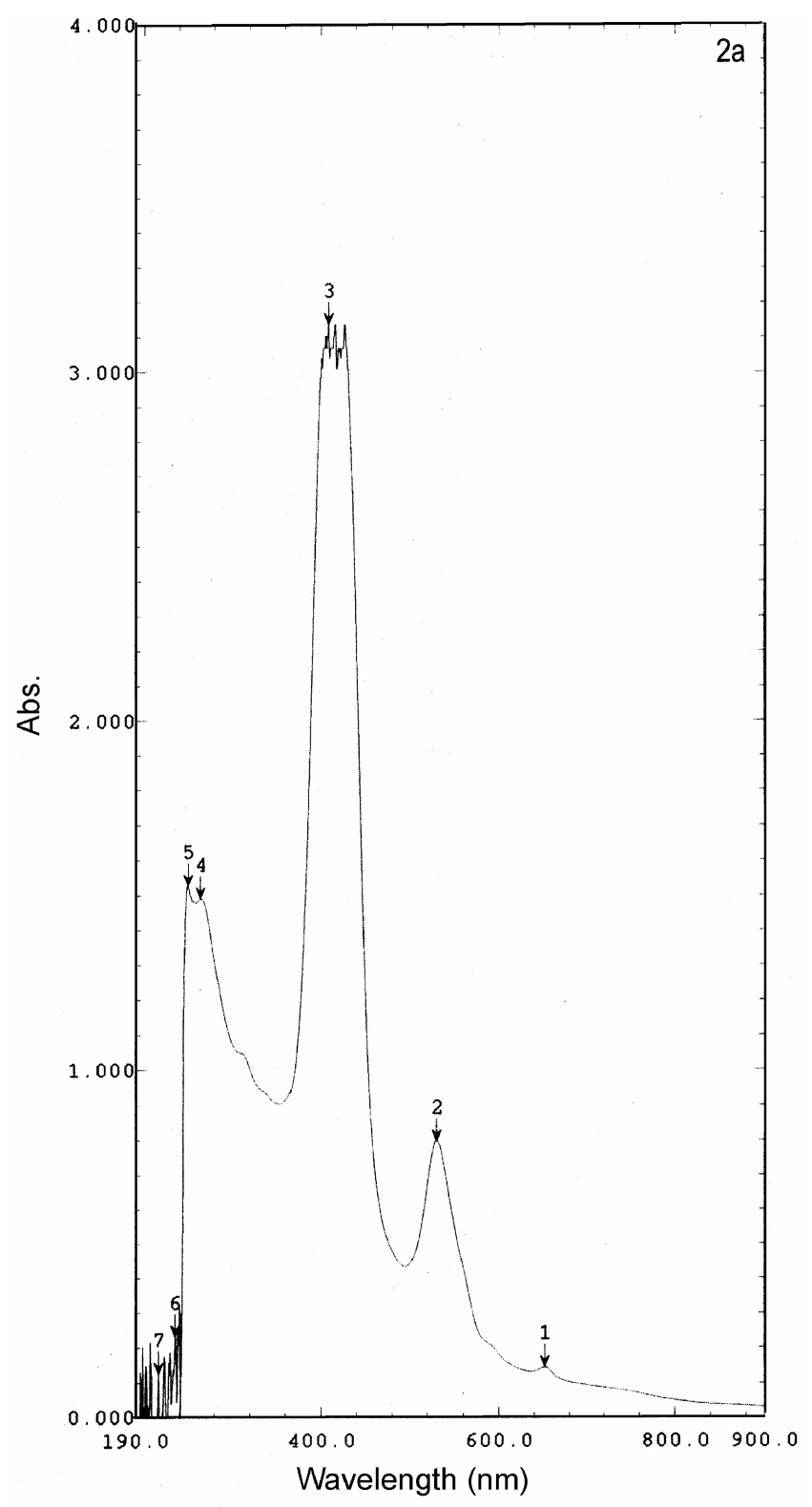

Figure 5. UV-visible spectrum of 2a. tural and dynamic aspects of porphyrins as well as their role in biological system. ${ }^{17}$ In case of paramagnetic systems one or more unpaired electrons may reside either on the $\pi$-ligand system or in the central metal atom or in both.

The values of g-tensor are in tables 3 and 4. For complexes (1c) and (2c), the anisotropy in the $g_{\|}=2.203$ and $g_{\perp}=2.05$ leads to $\mathrm{D}_{4} \mathrm{~h}$ symmetry of compound (square planar) around the $\mathrm{Cu}(\mathrm{II})$ ion. The splitting of spectra into four lines at LNT gives hyperfine constant $a=178 \mathrm{G}$ which confirms the ground state of $\mathrm{Cu}$ (II) ion is as $S=1 / 2$. The unpaired electron of the metal ion interact with $\mathrm{Cu}$ (II) nucleus with the nuclear spin $I=3 / 2$ resulting in splitting of spectrum into four lines. This confirms the copper is in +2 state oxidation state, with $S=1 / 2$ as a spin state resulting in a single line main EPR spectra.

Moreover, the value of G calculated as $g_{\|}-2 / g_{\perp}-2$ comes out to be $>4$ for both the compounds which leads to packing of molecular planes one above the other. This confirms the planar arrangement of porphyrin ring in the three-dimensional space.

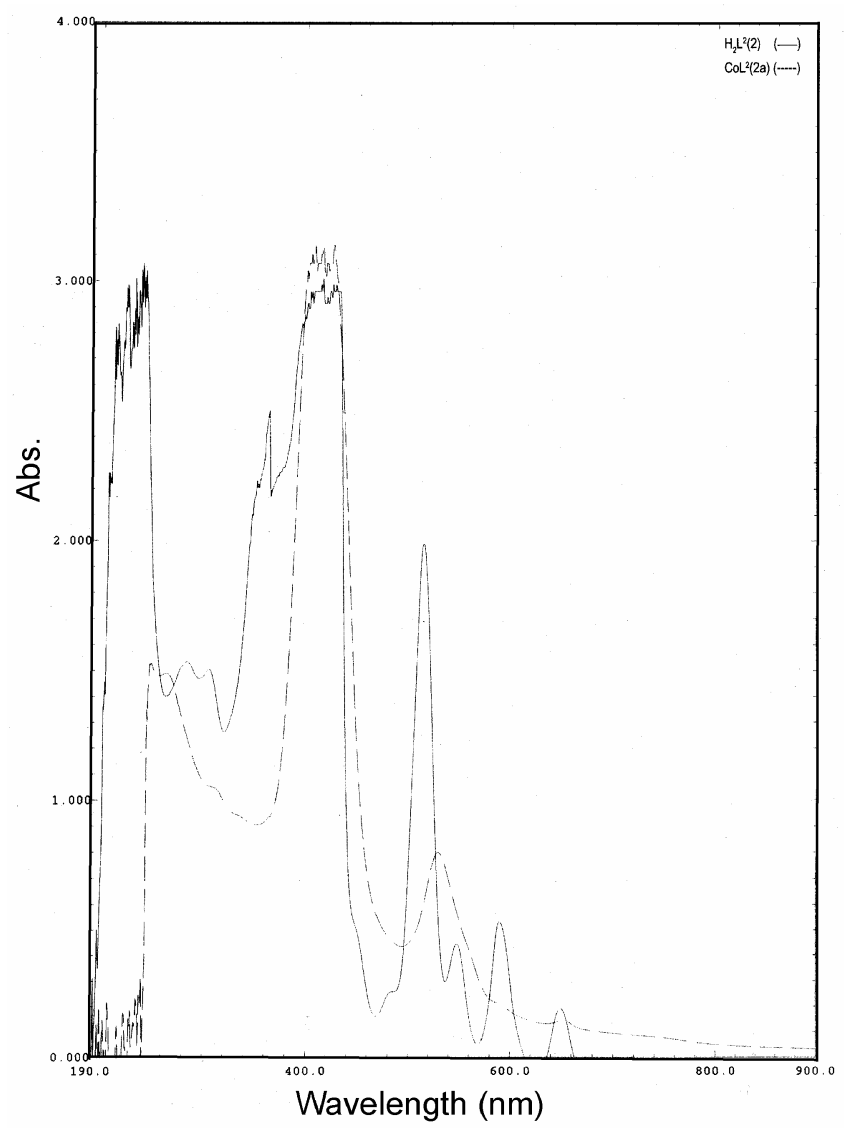

Figure 6. Comparison of UV-visible spectrum of ligand $\mathrm{H}_{2} \mathrm{~L}^{2}(\mathbf{2})$ and $\mathrm{CoL}^{1}(\mathbf{2 a})$. 
Table 5. Excitation and emission spectral data for compound (2d, $\left.\mathrm{ZnL}^{2}\right)$.

\begin{tabular}{lc}
\hline Emission spectra $\left(\right.$ in $\left.\mathrm{CHCl}_{3}\right)$ & Excitation spectra (in $\left.\mathrm{CHCl}_{3}\right)$ \\
\hline$\lambda_{\mathrm{ex}}=555.0 \mathrm{~nm}$ & $\lambda_{\mathrm{ex}}=603.0 \mathrm{~nm}$ \\
$\lambda_{\mathrm{em}}=604.0 \mathrm{~nm}$ & $\lambda_{\mathrm{em}}=604.0 \mathrm{~nm}$ \\
\hline
\end{tabular}

Microwave frequency: $9.762770 \mathrm{GHz}$

Microwave power: $4 \mathrm{~mW}$

Modulation frequency: $100 \mathrm{kHz}$

Receives gain: $5.02 \times 10^{-4}$

\subsection{Fluorescence spectra}

Fluorescence spectrum of $\mathrm{Zn}$ complex was studied. The excitation spectrum of fluorescence is in agreement with absorption spectrum. This implies that the fluorescence does not originate from some impurities. The excitation was carried out in visible range. The complex shows fluorescence behaviour (table 5).

The emission spectra has three peaks at 604,649 and $785 \mathrm{~nm}$ whereas excitation spectra have four peaks at $412,434,556$ and $603 \cdot 0 \mathrm{~nm}$.

\section{Acknowledgements}

P B Gujarathi thanks the University Grants Commission, New Delhi for teacher fellowship under Faculty Improvement Programme.

\section{References}

1. Kadish K M, Smith K M and Guilard R (eds) 2000 The porphyrin handbook (New York: Academic Press) vol 14 and reference cited therein.

2. Egger N G, Motamedi M, Pow-Sang M, Orihuela E and Anderson K E 1996 Pharmacology 52362
3. Nakjima S, Sokaka I and Takemura T 1996 Drug Delivery Syst. 11105

4. Winkelman J, Rubenfeld S and Mcafee J $1964 \mathrm{~J}$. Nucl. Med. 5462

5. Meunier B 1992 Chem. Rev. 921411

6. (a) Sternberg E D and Dolpin D 1998 Tetrahedron 54 4151; (b) Bonnett R 1995 Chem. Soc. Rev. 2419

7. (a) Wagner R W and Lindsey J S $1994 \mathrm{~J}$. Am. Chem. Soc. 119 9759; (b) Osuka A and Shimidzu H 1997 Angew. Chem., Int. Ed. Engl. 36135

8. (a) Kurreck H and Huber M 1995 Angew. Chem. Int. Ed. Engl. 34 849; (b) Wasielewski M R 1992 Chem. Rev. 92435

9. (a) Fiel R B and Biomel J 1989 Structure and Dynamics 6 1259; (b) Bromley S D, Ward B W and Dabrowiak J C 1986 Nucleic Acid Res. 14 9133; (c) Pasternack R F and Gibbs E J 1989 ACS Symp. Ser. 402 59; (d) Sari M A, Battioni J P, Dupre D, Mansuy D and Le Peg J B 1990 Biochemistry 294205

10. Battersby A R and MacDonald E 1975 In Porphyrins and metalloporphyrins (ed.) K M Smith (Amsterdam: Elsevier)

11. Morgan B and Dolphin D 1987 In Metal complexes with tetrapyrrole ligands $\mathrm{I}$. (ed.) J W Buchler (Berlin and Heidelberg, Germany: Springer Verlag)

12. Adler A D, Longo F R, Finarelli F C, Assour J and Korsakoff L 1967 J. Org. Chem. 32

13. Marsh D F and Mink L M 1996 J. Chem. Edu. 73 1188

14. Thomas D W 1985 J. Am. Chem. Soc. 815111

15. He Y F, Wei D B and Chen H 1998 Synth. Commun. 282843

16. Liu S Q, Sun H R, Sun Z T, Xu Ji Q and Li D M 2000 Synth. Commun. 302009

17. Smith K M 1975 Porphyrins and metalloporphyrins (Amsterdam, The Netherlands: Elsevier Scientific Publishing Co.) Chapter 12, p 454 